\title{
Diskursus Peminggiran Anak Jalanan
}

Syiqqil Arofat

\begin{abstract}
Abstrak
Diskursus pembangunan sering mengeksklusi kelompok yang dianggap mengganggu tatanan sosial; salah satunya adalah penanganan anak jalanan oleh pemerintah daerah di Kota Tangerang Selatan. Implementasi kebijakan yang dikembangkan oleh pemerintah daerah sering hanya bersifat instrumental, bahkan cenderung represif, serta tidak mengatasi akar persoalan anak jalanan. Hal itu merupakan konsekuensi dari konstruksi sosial, terutama melalui penetapan stigma-stigma negatif bagi anak jalanan, yang dikembangkan oleh para aktor pembangunan. Sehingga ketimpangan sosial pun bertahan tanpa adanya solusi kreatif dalam pemberdayaan anak jalanan. Karenanya, tulisan ini berupaya meninjau diskursus pembangunan sosial dan konsekuensinya bagi anak jalanan, serta mengusulkan pola pembangunan sosial yang lebih kreatif dan partisipatif dalam menangani anak jalanan.
\end{abstract}

Key words: diskursus pembangunan, eksklusi sosial, anak jalanan, ruang alternatif.

\section{Pendahuluan}

Selama ini, kota selalu didengungkan sebagai pusat perekonomian yang ditandai oleh padatnya aktivitas produktif, dan bahkan cenderung dikagumi dari bangunanbangunan megah yang menjulang tinggi. Dengan semakin terbatasnya peluang kerja di pedesaan, banyak penduduk desa terdorong untuk mengadu nasib di perkotaan, dan bahkan tidak banyak yang menyadari kompleksitas persoalan yang menyelimuti penduduk miskin kota. Setidaknya terdapat dua persoalan besar yang menjadi pusat perhatian dalam kajian sosiologi kota, yaitu kepadatan penduduk dan ketimpangan sosial. Kepadatan penduduk kota terjadi melalui dua faktor: (1) jumlah kelahiran yang cenderung lebih besar daripada jumlah kematian, dan (2) kecenderungan penduduk desa untuk melakukan migrasi ke daerah perkotaan (William G. Flanagan, 2010: 173).

Sedangkan ketimpangan sosial merupakan dampak dari kesenjangan distribusi kekayaan di perkotaan, terutama melalui dinamika perekonomian yang tidak seimbang antara masyarakat kelas menengah ke atas, yang memiliki kesempatan dan keahlian untuk membangun jaringan ekonomi, dan masyarakat kelas bawah yang memilki keterbatasan akses terhadap sumber daya ekonomi. Selain itu, kemiskinan dianggap sebagai penyebab munculnya bermacam persoalan lainnya di perkotaan, seperti pemukiman kumuh, kriminalitas dan gelandangan. Dinamika inilah yang terus melanggengkan ketimpangan sosial di perkotaan.

Di sisi lain, pendekatan pembangunan yang sering dilakukan pemerintah cenderung menuntut penyesuaian masyarakat: anggota masyarakat yang memiliki akses perekonomian mampu membangun jaringan dan mengakumulasi modal ekonomi, sementara anggota masyarakat yang tidak memiliki akses perekonomian semakin tereksklusi dan terperosok 
dalam kemiskinan, terutama saat pembangunan lebih menekankan pertumbuhan ekonomi (Gerry Rodgers, 1995: 296). Sehingga pembangunan hanya melahirkan ketimpangan distribusi kekayaan yang menggerus pendapatan sebagian besar masyarakat, membentuk ketimpangan sosial, dan memperuncing kemiskinan perkotaan. Berdasarkan kondisi inilah Dudley Seer, seperti dikutip John Martinussen (1997: 294), menyatakan pentingnya menggeser fokus pembangunan yang menekankan pada pertumbuhan ekonomi, dan lebih memberikan perhatian pada tiga isu utama: kemiskinan, pengangguran dan ketimpangan sosial.

Lebih ironis lagi, diskursus pembangunan ekonomi mengusung nilai-nilai kemajuan yang harus diupayakan dan keterbelakangan yang harus ditinggalkan. Pembedaan antara kemajuan dan keterbelakangan berimplikasi pada terbentuknya persepsi yang merendahkan anggota masyarakat yang memiliki keterbatasan dalam mendukung nilai-nilai kemajuan. Persepsi itu pun dijadikan pembenaran terhadap pengabaian atau bahkan penyingkiran anggota masyarakat yang dianggap terbelakang. Teague dan Wilson, seperti dikutip David Byrne (2005: 40), mengungkapkan bahwa warga negara diakui dan dirangkul oleh aktoraktor pembangunan hanya apabila berperan aktif di ruang publik dan mematuhi nilai-nilai dan aturan-aturan yang dipegang bersama.

Berdasarkan dinamika pembangunan itulah sebagian anggota masyarakat tersingkir dari dinamika pembangunan. Namun, yang mengalami dampak paling besar adalah anakanak miskin kota yang terpaksa harus menjadi gelandangan atau pengamen di jalanan, sehingga mereka pun tidak dapat memperoleh hak-hak sebagai warga negara, tanpa akses pendidikan, bergelut dalam kerasnya kehidupan jalanan, dan bahkan mengalami tindakan represif dari aparat pemerintah daerah. Terjadinya eksklusi sosial dikonstruksi oleh pemerintah sebagai pemborosan, ketidakefektivan dan ketimpangan moral; lalu strategi modernisasi dilekatkan sebagai visi pemberdayaan terhadap masyarakat yang bertanggungjawab pada kesejahteraannya masing-masing dan keluarganya. Karena itulah, dalam pandangan Williamson, diskursus pembangunan ini bukan hanya merupakan bahasa moral, tetapi juga bahasa manajerial (David Byrne, 2005: 59). Akhirnya, dinamika tersebut hanya memperpanjang dan memperumit lingkaran kemiskinan.

Dalam upaya melindungi kehidupan anak, Indonesia menjadi salah-satu negara yang turut mengesahkan konvensi perjanjian internasional yang diwujudkan dalam "The World Convention On The Rights of The Child 1989 (Konvensi Hak Anak/KHA)”. Pemerintah Indonesia juga memperkuat komitmennya untuk memenuhi hak-hak anak dengan memberlakukan Undang-Undang Nomor 23 Tahun 2002 tentang Perlindungan Anak, meski dalam implementasinya masih banyak dipertanyakan. Dalam Pasal 4 UU No. 23/2002 dinyatakan bahwa setiap anak berhak untuk hidup, tumbuh, berkembang, dan berpartisipasi secara wajar sesuai dengan harkat dan martabat kemanusiaan, serta mendapatkan perlindungan dari kekerasan dan diskriminasi. Seiring dengan diterapkannya 
sistem desentralisasi, pemerintah daerah saat ini bertanggung jawab untuk mengatur dan mengimplementasikan kebijakan perlindungan anak tersebut.

Namun, implementasi kebijakan perlindungan anak yang telah dilakukan tidak mengatasi persoalan anak jalanan, tetapi malah melahirkan tindakan-tindakan diskriminatif dan represif. Tulisan ini berupaya menelusuri ketimpangan sosial dalam diskursus pembangunan Kota Tangerang Selatan, yang menjadi akar persoalan munculnya anak jalanan dan mengeksklusi anak jalanan untuk memperoleh hak-hak sebagai warga negara. Sehingga kajian ini diharapkan mampu memberikan masukan bagi pembuat dan pelaksana kebijakan sosial untuk menemukan solusi alternatif dalam membangun kehidupan anak jalanan.

\section{Diskursus dan Eksklusi Anak Jalanan}

Dengan luas wilayah 147,19 Km2, Kota Tangerang Selatan memiliki kepadatan penduduk yang mencapai 7.312 orang/Km2. Berdasarkan data BPS Tangerang Selatan 2013, jumlah penduduk Kota Tangerang Selatan adalah 1.405.170. Tingginya kepadatan penduduk tidak hanya disebabkan oleh pertambahan secara alamiah, tetapi juga dari kecenderungan masuknya para migran, seperti banyaknya perumahan-perumahan baru yang dibangun sebagai daerah yang berbatasan langsung dengan Kota Jakarta. Tingkat kesejahteraan masyarakat pun cenderung beragam. Kecamatan yang memiliki penduduk kaya paling besar adalah Ciputat. Namun, meski memiliki penduduk miskin yang jumlahnya lebih sedikit daripada penduduk kaya, ironisnya Kecamatan Ciputat juga memiliki jumlah anak terlantar yang paling besar di Tangerang Selatan, yaitu 251 jiwa (Badan Pusat Statistik Kabupaten Tangerang, 2013).

Dalam menanggulangi anak jalanan, meski belum memiliki kebijakan khusus tentang perlindungan anak jalanan, Pemerintah Kota Tangerang Selatan memasukkan anak jalanan dan terlantar sebagai salah satu kategori Penyandang Masalah Kesejahteraan Sosial (PMKS) dalam Rencana Pembangunan Jangka Menengah Daerah (RPJMD) yang disusun oleh Badan Perencanaan Pembangunan Daerah (BAPPEDA) Tangerang Selatan. Dalam RPJMD Tangerang Selatan disebutkan:

"Keberadaan PMKS merupakan potensi terhadap bertumbuhkembangnya ketunaan sosial dan penyimpangan perilaku masyarakat. Kasus gelandangan dan pengemis semakin merebak terutama pada pusat-pusat kota, pasar, terminal dan merupakan salah satu potensi permasalahan yang dapat menganggu ketentraman dan ketertiban umum di wilayah Kota Tangerang Selatan. Berbagai upaya pencegahan terhadap berkembangnya gelandangan dan pengemis ini tengah dipersiapkan dan akan dilaksanakan oleh Pemerintah Kota Tangerang Selatan."

Selain itu, dalam APBD tahun 2012, Pemerintah Kota Tangerang Selatan juga telah menganggarkan secara khusus sebesar Rp 120,000,000 untuk pelatihan keterampilan dan 
praktik belajar kerja bagi anak terlantar, anak jalanan dan anak nakal. Melalui rancangan pembangunan inilah pemerintah Kota Tangerang Selatan menerapkan program-program penanggulangan anak jalanan. Berdasarkan RPJMD Tangsel, pemerintah daerah dituntut untuk melakukan kordinasi dengan Dinas Daerah secara komprehensif, terpadu dan berkelanjutan, yang meliputi perencanaan, pelaksanaan, pelaporan, pengawasan, dan pembinaan. Namun, nampaknya kordinasi yang dilaksanakan oleh Pemerintah Daerah masih bersifat prosedural, dengan program-program pelatihan yang kurang produktif.

Pemerintah daerah, yang direpresentasikan oleh Dinas Sosial, bertanggung jawab dalam menangani banyaknya anak terlantar tersebut. Model penanganan yang sering dilakukan adalah razia anak jalanan. Dinas Sosial bekerja sama dengan Satpol-PP bertugas menjaring dan menangkap anak jalanan tersebut. Kepala Dinas Sosial, Tenaga Kerja dan Transmigrasi (Dinsosnakertrans) Kota Tangsel, Purnama Wijaya, mengungkapkan bahwa selama bulan Juni 2012, terdapat 1.055 PMKS yang terjaring razia; di antaranya adalah gelandangan sebanyak 47, pengemis sebanyak 100, eks narapidana (Napi) sebanyak 118, anak berhubungan dengan hukum sebanyak 36, Napza sebanyak 215, penderita HIV sebanyak 326, dan anak jalanan sebanyak 163 orang (www.tangsel-pos.com).

Aparat keamanan cenderung melihat anak jalanan ini sebagai pengganggu ketertiban, sehingga mereka tidak segan-segan bertindak represif. Konsekuensinya, anak jalanan juga memusuhi aparat keamanan dan tidak segan-segan melanggar aturan-aturan dan ketertiban umum. Kepala Satpol-PP Kota Tangsel, Azhar Syamun, pernah menyatakan bahwa sasaran operasi razia adalah para gelandangan dan pengemis yang dianggap mengganggu ketertiban dan kenyamanan masyarakat (www.satpolppkotatangsel.info). Sempat terjadi kejar-kejaran saat petugas akan menangkap anak jalanan, dan bahkan pernah anak yang masih di bawah umur (5 tahun) dan meminta-minta di lampu merah meronta dan menangis ketika akan diangkut oleh petugas keamanan (www.metro.sindonews.com). Setelah terjaring razia, mereka didata dan biasanya dilepas kembali dengan perjanjian tidak akan mengulanginya lagi, atau dikirim ke pesantren untuk mendapatkan pembinaan moral, sebab Pemerintah Kota Tangerang Selatan masih belum memiliki tempat rehabilitasi. Namun jika sudah tertangkap berkali-kali, anak jalanan ini dikirim ke panti sosial rehabilitasi di Pasar Rebo, Jakarta Timur (www.bantentoday.com).

Perilaku anak jalanan yang meresahkan masyarakat tersebut dianggap sebagai persoalan moral dan solusinya juga harus berupa pembinaan moral. Salah satu tindakan yang dilakukan Satpol-PP terhadap anak punk yang terkena razia adalah mengirimkannya ke pesantren. "Mereka kita berikan pembinaan setelah tertangkap, kita berikan pemahaman keagamaan dengan dikirim ke pesantren Masjid Annur Serpong, minimal mereka mengerti bagaimana berwudlu dan sholat berjamaah," ujar Mawardi, Kapolsek Serpong (www. lenteranews.com). 
Media komunikasi memiliki peran penting sebagai salah satu rezim yang turut mengarahkan diskursus pembangunan. Seperti diungkapkan Hardt dan Negri (2000: 32), industri media tidak hanya berperan mengungkapkan tatanan sosial, namun juga berkonstribusi dalam mengendalikan arah imajinasi tentang kehidupan sosial. Media komunikasi menyediakan saluran tentang apa yang harus dibayangkan dan bagaimana membayangkannya. Diskursus pembangunan kota lebih banyak memunculkan pentingnya pengendalian keamanan dan kenyamanan sosial, bukan mengatasi ketimpangan sosial dan pemerataan akses pendidikan dan ekonomi bagi anak jalanan.

Diskursus pembangunan ini terus bersirkulasi dalam ruang publik; individu atau kelompok saling berhubungan dan bertukar cara pandang. Diskursus bukan berupa model pemaknaan melalui bahasa yang stabil dan konsisten, namun lebih merupakan persaingan dalam membangun relasi kuasa dalam kerangka historis tertentu (Michael Foucault, 1980: 144). Namun, sebagaimana diungkapkan Anna Tsing (2000: 327), proses keterhubungan individu atau kelompok tidak bergerak secara linear menuju kondisi yang sepenuhnya seragam, tetapi para aktor mengembangkan jaringan aliansi dan dukungan atau membangun relasi kuasa, serta mengupayakan konfigurasi ruang tertentu sesuai dengan konstruksi makna yang diusungnya. Kolaborasi elitis antara pemerintah daerah, petugas keamanan, dan tokoh agama, dalam menciptakan ketentraman kota, atau lebih tepatnya kenyamanan masyarakat kelas menengah ke atas, menjadi efektif dalam menyingkirkan kepentingan anak jalanan, bahkan mereka cenderung menggunakan pencitraan tentang kebaikan bersama demi mempertahankan legitimasi kekuasaannya, yang disebut James Scott (1990: 18) sebagai strategi dominasi yang paling samar. Sementara itu, anak jalanan berusaha kabur saat melihat aparat keamanan supaya tidak terkena razia, sehingga mereka pun semakin tersingkir dalam diskursus sosial dan hanya mampu melakukan resistensi secara tersembunyi.

Kesalahan analisis banyak dilakukan oleh pengkaji sosial saat mengabaikan adanya berbagai kekuatan yang saling bersaing dan berkolaborasi dalam dinamika sosial, yang justru lebih banyak dikuasai oleh kelas menengah ke atas dan tidak selalu bersifat demokratis. Seperti disadari oleh Restrepo, sebagaimana dikutip García-Guadilla (2005), bahwa kekuatan yang dibangun oleh organisasi sosial cenderung hanya mempromosikan sebuah nilai atau kepentingan tertentu, rentan menciptakan ketimpangan sosial, serta memperuncing eksklusi sosial. Karenanya, demokrasi perlu ditinjau lebih jauh berdasarkan polarisasi sosial, ekonomi, politik dan ideologi, dengan mengidentifikasi berbagai nilai yang melatari terbentuknya pola pembangunan sosial. Demi mempertahankan kepentingan anggota dari kelas tertentu, berbagai organisasi cenderung membangun aliansi yang akhirnya mengancam demokrasi itu sendiri.

Pengembangan aliansi dan dukungan tersebut hanya dimungkinkan melalui legitimasi posisi dan peran lembaga dalam jaringan sosial. Menurut Sarah Lister (2003), terdapat tiga aspek yang belum banyak dikaji dalam terbentuknya legitimasi organisasi: (1) lingkungan 
eksternal, (2) karakteristik legitimasi, dan (3) identifikasi simbolik. Ketiga aspek ini banyak mewarnai terbentuknya relasi kuasa. Pertama, lingkungan eksternal. Organisasi sosial berada dalam konteks dan konstruksi sosial tertentu, yang terdiri dari berbagai stakeholders. Sikap berbagai kalangan ini berkonstribusi pada penetapan legitimasi pembangunan, serta menjadi acuan pemerintah dalam melakukan tindakan strategis.

Kedua, karakteristik lagitimasi. Scott, seperti dikutip Lester (2003), mengungkapkan tiga karakteristik legitimasi dalam lingkungan organisasi: pengaturan institusional, kognitif dan normatif. Legitimasi pengaturan berkaitan dengan aturan-aturan institusional yang diterapkan untuk menjaga kestabilan dan keteraturan organisasi. Legitimasi normatif memerlukan kecocokan antara nilai-nilai yang diusung organisasi dan nilai-nilai masyarakat secara luas. Sedangkan legitimasi kognitif berkaitan dengan penyesuaian dengan struktur kognitif yang terbentuk dalam masyarakat, yang biasanya sudah diterima apa adanya. Dengan memahami keragaman karakteristik legitimasi tersebut, organisasi sosial cenderung mengalami kontestasi dan ketegangan dalam membangun legitimasi posisi dan perannya dalam dinamika sosial, yang cenderung memperkuat diskursus dominan.

Ketiga, identifikasi simbolik. Simbol-simbol tertentu mampu meningkatkan legitimasi. Dalam penelitian terhadap tujuh organisasi di Guetemala, Sarah Lister (2003) menemukan setidaknya terdapat tiga simbol yang menguatkan legitimasi: selatan, lokal dan partner. Istilah "selatan" menunjukkan lokasi penduduk di belahan dunia selatan yang perlu dibantu oleh lembaga donor di negara-negara belahan "utara" yang kaya. Namun, yang dimaksud dengan penduduk selatan tidak dapat diidentifikasi secara jelas. Hanya terdapat kecenderungan homogenisasi dengan pembedaaan mencolok antara "utara" sebagai negara kaya dan "selatan" sebagai negara miskin. Istilah "lokal" juga cenderung digeneralisasi. Sementara dalam kasus anak jalanan, simbol-simbol yang menguatkan legitimasi pola pembangunan represif adalah kenakalan anak, ketentraman kota, dan sebagainya.

Pendekatan pemerintah, dengan penggunaan cara represif, dalam menangani anak jalanan sering memunculkan berbagai masalah, namun banyak kalangan yang membenarkan tindakan ini, sehingga pola pembangunan represif semacam ini mendapatkan legitimasi yang kuat dari mayoritas masyarakat. Mungkin cara represif masih bisa diterima apabila pemerintah daerah mampu menyediakan ruang bagi anak jalanan untuk bertahan hidup dan mengembangkan bakat dan minatnya, sesuai dengan yang diamanatkan oleh undang-undang. Namun, jika pemerintah daerah tidak memilki solusi pemberdayaan ini, cara represif hanya akan memancing agresivitas anak, sehingga relasi antara anak dan pemerintah pun akan semakin memburuk. Satpol-PP memandang anak jalanan sebagai pengganggu ketertiban dan ketentraman, sehingga mereka tidak segan-segan menggunakan paksaan untuk menangkap anak tersebut. Tindakan Satpol-PP ini juga sering memicu perlawanan balik dari anak-anak jalanan. Pola yang terus berulang ini menjadikan hubungan antara anak jalanan dan aparat pemerintah diwarnai dengan ketegangan dan permusuhan. 
Pemerintah daerah menganggap anak jalanan sebagai anak nakal yang liar dan tidak mau diatur. Begitu pula anak jalanan yang menganggap pemerintah daerah tidak memahami dan kurang peduli pada kondisinya cenderung meluapkannya dengan melanggar aturan dan ketertiban umum. Seiring dengan keengganan anak jalanan untuk menuruti aturan-aturan yang berlaku, pemerintah daerah lebih menekankan pembinaan moral dalam menanggulangi kenakalan anak jalanan. Pendekatan ini menuntut anak untuk menjadi warga negara yang baik sekaligus bersikap pasif, serta mengabaikan kreativitasnya. Padahal kondisi semacam itulah yang sangat tidak disukai anak jalanan, sehingga dinamika penanganan anak jalanan tidak pernah membuahkan hasil.

Konsensus pembangunan di antara para aktor sosial disebabkan suksesnya penyebaran diskursus dominan yang mempersempit cakupan praktik demokratis. Salah satu faktornya adalah ketelibatan aktor-aktor organisasi kemasyarakatan dalam melegitimasi kebijakan pemerintah. Pembicaraan yang berkembang di antara penduduk adalah tentang keamanan dan ketentraman di ruang publik, sehingga wacana publik didominasi oleh isuisu tentang kenakalan anak yang terinternalisasi dalam pikiran penduduk. Bahkan media massa dijadikan alat untuk menyebarkan dan melegitimasi wacana dominan ini ketimbang untuk membuka cara pandang baru tentang hilangnya akses anak jalanan terhadap ruang pengembangan kreativitas dan produktivitas. Dalam kondisi inilah proses pendisplinan subjek, sebagaimana konsepsi Foucauldian, menjadi semakin efektif dalam pembentukan diskursus dominan. Konsensus semacam inilah yang disebut Mouffe sebagai konsensus palsu (Gaynor, 2011).

\section{Ruang Alternatif bagi Anak Jalanan}

Selain penangan anak jalanan yang dilakukan pemerintah daerah, terdapat enam yayasan panti asuhan anak di Tangerang Selatan yang menyediakan fasilitas dan tempat bagi anak jalanan. Yayasan swasta ini memiliki program pembinaan, pengajaran dan pemberdayaan yang dirancangnya sendiri demi memenuhi kebutuhan pendidikan anakanak asuhnya. Para pengelola yayasan memiliki kedekatan emosional dengan anak-anak asuhannya. Salah satu yayasan anak yang diteliti penulis adalah Panti Asuhan Amal Wanita Ciputat. Sebagian besar anak asuh di yayasan ini berasal dari luar kota dengan latar belakang yang beragam. Anak terlantar yang diasuh di yayasan ini tidak ada yang mengamen lagi di jalanan, sebab yayasan telah menanggung seluruh biaya hidup anak asuhnya dan melarang mereka untuk melakukan aktivitas di jalanan.

Pernah Dinas Sosial Tangsel berupaya melakukan kerja sama dengan Panti Asuhan Amal Wanita Ciputat. Saat ditemukan anak terlantar yang tidak diketahui identitasnya, biasanya Dinas Sosial Tangsel menawarkan kepada panti asuhan swasta yang bersedia mengasuhnya. "Pernah Dinas Sosial menghubungi kami untuk mengasuh anak terlantar yang baru ditemukan," ungkap Khairul Amri, Pembina di Panti Asuhan Amal Wanita 
Ciputat (Wawancara pribadi pada 15 Desember 2013). Namun, jarang panti sosial swasta menerima anak asuhan baru, sebab selain terbatasnya fasilitas, pihak yayasan juga dituntut untuk membiayai kehidupan dan sekolah anak asuh hingga tingkat SMA.

Dinas Sosial Tangerang Selatan hanya pernah memberikan bantuan tahunan dan mengundang perwakilan anak panti sosial untuk mengikuti pelatihan sehari. Selebihnya, Dinas Sosial Tangerang Selatan tidak pernah menjalin kerja sama dalam mengembangkan pelatihan keterampilan berkelanjutan bagi anak-anak asuhan. "Kegiatan dan program pembinaan anak asuh kami upayakan dan kembangkan sendiri," lanjut Amri. Di antara kegiatan pelatihan yang disediakan Yayasan Amal Wanita adalah menjahit, berternak, berkebun dan mengetik/komputer.

Dalam mengembangkan kegiatan kemasyarakatan, Yayasan Amal Wanita lebih banyak bekerjasama dengan LSM. Misalnya, pihak yayasan pernah menyelenggarakan pengobatan penyakit katarak bagi masyarakat sekitar yang bekerjasama dengan Lions Club Jakarta. Sedangkan untuk pemeliharaan kesehatan anak asuh, pihak yayasan bekerjasama dengan Puskesmas setempat. Pihak puskesmas bersedia datang ke Yayasan Amal Wanita untuk memberikan pengobatan gratis bagi anak-anak yang diasuh oleh yayasan ini. "Paling itu, mereka datang ke sini dan memeriksa anak secara gratis," papar Amri.

Berbeda dengan anak-anak yang berkeliaran di jalanan, anak terlantar yang sudah diasuh oleh Yayasan Panti Asuhan Amal Wanita Ciputat memiliki tempat tinggal, belajar dan bermain di yayasan ini. Mereka tidak lagi diizinkan mengamen di jalanan dan selalu diawasi untuk mengikuti kegiatan-kegiatan baik di yayasan maupun di sekolah. Sehingga tidak ada lagi anak asuh yang terkena razia Satpol-PP. Aturan-aturan ketat pun berhasil diterapkan untuk memonitor perkembangan anak jalanan, meski orientasi pendidikan yang dikembangkan di yayasan ini serupa dengan pendidikan formal.

Pendekatan pembangunan dengan cara konvensional yang dilakukan pemerintah menjadi kendala dalam menemukan solusi alternatif. Pemerintah cenderung menyelenggarakan pelatihan kerja konvensional, seperti mengemudi, menjahit, beternak, dan sebagainya, padahal orang dewasa yang menguasai keterampilan ini pun mengalami kesulitan untuk meningkatkan taraf hidupnya seiring dengan ketatnya persaingan dalam dunia usaha. Dengan kata lain, melalui pembangunan konvensional dengan pendekatan linear, niat baik pemerintah justru dapat menjerumuskan anak jalanan kepada kondisi persaingan pasar, yang kemungkinan besar juga dapat tersingkir seperti orang tua mereka. Sehingga lingkaran kemiskinan pun terus berputar dan diwariskan turun-temurun.

Oleh karena itulah banyak anak jalanan yang tidak suka tinggal di panti sosial disebabkan aturan-aturan ketat yang diterapkannya, sehingga beberapa organisasi sosial yang peduli pada pendidikan anak jalanan tergugah untuk menyediakan sarana pendidikan kreatif berupa rumah singgah dan media pemberdayaan kreativitas anak jalanan. Salah satu lembaga yang diteliti penulis adalah Sanggar Kreatif Anak Bangsa (SKAB) Ciputat. 
Sanggar ini mengajak anak jalanan untuk tinggal, bermain dan belajar tanpa terikat pada aturan-aturan tertentu. Sehingga anak-anak jalanan bebas berkunjung dan belajar dengan para tutor yang lebih banyak dari mahasiswa UIN Jakarta, dengan agenda pengajaran dan pembinaan yang telah disepakati bersama.

Menurut Dicky Komaruzzaman, pembina SKAB, anakjalanan yang dibinanya banyak yang pernah berada di panti sosial, tetapi kemudian tidak betah dan kabur. Berbagai aturan ketat yang diterapkan di panti asuhan menjadi kendala bagi anak jalanan untuk berkembang sesuai dengan bakat-bakatnya. Menururtnya, pembinaan anak jalanan yang diselenggarakan oleh pemerintah cenderung berorientasi pada pendidikan konvensional yang mengandaikan kepatuhan anak pada aturan-aturan dan pengajaran pengetahuan-pengetahuan umum, sehingga anak menjadi pasif dan bosan. Anak-anak bebas mengekpresikan bakat-bakat, termasuk potensi-potensi kenakalannya. "Kita lebih menekankan pendekatan kesadaran dari anak jalanan sendiri," ungkap Dicky. Pendekatan persuasif yang digunakan di SKAB berhasil menyadarkan anak-anak nakal untuk mempertimbangkan konsekuensi dari perilaku nakalnya, sehingga setidaknya anak-anak berlahan-lahan mampu mengubah sikap buruknya tanpa harus mengorbankan bakat-bakat dan kreativitasnya.

Pemerintah daerah pernah mengundang anak jalanan SKAB untuk mengikuti pelatihan komputer, padahal selain tidak adanya pembinaan yang berkelanjutan, anak jalanan juga tidak dapat membayangkan bagaimana pemanfaatan keterampilan komputer dengan kondisi kemiskinan yang dialaminya. Hal itu pula yang membuat pembina SKAB tidak memercayai pemerintah yang dianggap hanya berorientasi pada pelaksanaan proyek yang menguntungkan bagi mereka sendiri tanpa adanya komitmen terhadap pemberdayaan berkelanjutan bagi anak jalanan.

Oleh karenanya, berdasarkan pendekatan pendidikan partisipatoris, SKAB menyesuaikan program dan kegiatan pendidikan dengan bakat dan minat anak jalanan, meski ada juga pendidikan formal yang dimasukkan selama anak tetap menyukainya. Namun, SKAB lebih menekankan pengembangan kreativitas anak, seperti keterampilan lukis, musik, tari, teater, dan sebagainya. Dalam pengembangan kegiatan kreatif ini, SKAB berupaya mengajak tenaga-tenaga ahli, dari kalangan mahasiswa hingga tenaga profesional, sebagai tutor yang membantu perkembangan kemampuan anak jalanan.

Selain itu, SKAB juga berupaya membangun kerja sama dengan lembaga-lembaga lain untuk mengembangkan produktivitas kegiatan sekaligus mendorong anak-anak didik untuk terus berkarya. Salah satu kerjasama yang sedang dijalin adalah penerbitan ontologi cerpen yang bekerjasama dengan Penerbit Balai Pustaka. Sudah lama SKAB menyelenggarakan pelatihan menulis kreatif dengan melibatkan penulis-penulis dari kalangan mahasiswa, sedangkan pihak penerbit juga sudah menyanggupi untuk menerbitkan karya tulis anak jalanan ini. Meski demikian, SKAB masih belum memiliki jaringan yang luas untuk mengembangkan dan memamerkan karya-karya anak jalanan di tingkat nasional. 


\section{Kesimpulan}

Persoalananakjalananmerupakanpermasalahanyangkompleksdanmultidimensional. Pertama, persoalan struktural menjadi kendala saat penerapan pembangunan oleh birokrasi pemerintah cenderung hanya bersifat instrumental dan tidak mengatasi akar persoalan anak jalanan. Ketimpangan sosial pun terus bertahan tanpa adanya mobilitas vertikal. Kedua, persoalan kultural menjadi semakin runcing melalui penetapan stigma negatif dan tindakan represif oleh aktor pemerintah yang memicu ketegangan dan permusuhan. Padahal sistem nilai dan perilaku tidak dapat dipaksakan begitu saja dan tidak juga melalui komunikasi satu arah, seperti nasehat atau ceramah keagamaan; komunikasi satu arah hanya akan membuat anak jalanan bertambah bosan.

Dengan demikian, berdasarkan kompleksnya persoalan anak jalanan, dibutuhkan solusi-solusi alternatif, misalnya melalui media aktivitas dan kreativitas yang mendidik dan tentunya diminati oleh anak jalanan. Media tersebut diharapkan mampu mendorong anak jalanan untuk terus berkarya sehingga mereka mampu menghasilkan kreativitas bernilai tinggi. Pola penyaluran potensi anak jalanan ini perlu didukung dan dibangun di antara stakeholders, seperti pemerintah, lembaga swasta dan tokoh masyarakat. Untuk menyalurkan potensi dan bakat anak jalanan, sudah sepantasnya pemerintah daerah berkoordinasi dengan berbagai pihak, sehingga mampu bersama-sama menemukan media yang tepat dan dapat dikembangkan secara luas.

Akhirnya, pembangunan sosial membutuhkan aktor-aktor kreatif yang mampu mendobrak kerangkeng pembangunan dan mampu mengembangkan jaringan sosial demi memberikan media penyalur bagi bakat dan potensi anak jalanan, sehingga mereka dapat diberdayakan dan dibanggakan baik di level nasional maupun internasional. Sebab, tidak jarang anak jalanan memiliki kreativitas tinggi melebihi anak rumahan. Tantangan pembangunan sosial adalah bagaimana mengubah apa yang dianggap tidak berguna menjadi sesuatu yang berharga melalui media-media kreatif tersebut. Seiring berjalannya waktu, anak jalanan diharapkan tidak lagi dianggap sebagai “sampah" yang mengganggu ketertiban umum, tetapi sebagai generasi bangsa yang patut dibanggakan. 


\section{Bibliografi}

Byrne, David, Social Exclusion (2nd ed). London: Open University Press, 2005.

Flanagan, William G., Urban Sociology: Images and Structure. UK: Rowman \& Littlefield Publishers, 2010.

Foucault, Michael, Power/Knowledge: Selected Interviews and Other Writings 1972-1977. Britain: The Harvester Press, 1980.

Gaynor, Niamh. 2011. Associations, Deliberation, and Democracy: The Case of Ireland's Social Partnership. Jurnal Politics and Society. SAGE Publications.

García-Guadilla, María Pilar. 2005. The Democratization of Democracy and Social Organizations of the Opposition. Jurnal Latin American Perspectives, Issue 141, Vol. 32 No. 2.

Hardt, Michael dan Antonio Negri, Empire. USA: Harvard University Press, 2000.

Lister, Sarah. 2003. NGO Legitimacy: Technical Issue or Social Construct?. Jurnal Critique of Anthropology, Vol 23. London: SAGE Publications.

Martinussen, John, Society, State and Market: A Guide to Competing Theories of Development. London: Zed Books, 1999.

Rodgers, Gerry, Charles Gore, dan Jose B. Figueiredo (Ed.), Social Exclusion: Rhetoric, Reality, Responses. Geneva: International Labour Organization, 1995.

Scott, James C., Domination and The Arts of Resistence: Hidden Transcripts. New Haven dan London: Yale University Press, 1990.

Tsing, Anna, "The Global Situation" dalam Cultural Anthropology. American Anthropolological Association, 2000.

, Friction: An Ethnography of Global Connection. Princeton: Princeton University Press, 2005. 